\title{
IMPROVING THE PROCESS OF EMPLOYEE ADAPTATION IN HOSPITALITY ENTERPRISES BASED ON ISO 10018:2015 "QUALITY MANAGEMENT, GUIDELINES FOR EMPLOYEE ENGAGEMENT AND COMPETENCIES"
}

\author{
Iryna Chernysh', Mila Kozyk ${ }^{2}$
}

\begin{abstract}
The purpose of the article is to study theoretical and practical aspects of the process of adaptation of hospitality workers taking into account the requirements of today, namely, when the external environment is dynamic, difficult to predict, staff turnover is high, multitasking increases, and professional burnout accelerates. The methods of research are analysis and synthesis, induction and deduction, causal link between the process of adaptation of employees and the level of engagement that affects labor productivity, which justified the role and importance of the international quality standard ISO 10018: 2015 "Quality management, guidelines for employee engagement and competencies". The results of the study have established that with the development of the digital economy, opportunities for self-development are increasing, so modern professional development programs should be supplemented with a section on self-development. And this should be reflected in the employee ID card. Form a separate program of human capital development, where the adaptation program will be part of, providing a positive attitude to the enterprises of hospitality of the employees themselves, taking into account their competencies. Practical results. To improve the efficiency of the process of adaptation of hospitality workers it is necessary to implement the international quality standard ISO 10018: 2015 "Quality management, guidelines for employee engagement and competencies", which will address the organizational and methodological aspects of this process. Strengthen the role and importance of competencies that affect the quality of hospitality workers. The peculiarity of this approach is the use of all these processes on the basis of the quality control cycle. Value/originality. The originality lies in the use of the international practice of ISO 10018: 2015 "Quality management, guidelines for employee engagement and competencies" in the hospitality industry, where the human factor plays a key role and shapes their sustainable development.
\end{abstract}

Key words: adaptation, involvement, ISO standard, adaptation tools, benefits of adaptation, human capital, hospitality.

\section{JEL Classification: J24}

\section{Introduction}

Relevance of the topic lies in the fact that the process of adaptation is a process that accompanies people activities throughout their lives, both in everyday life and in professional activities. Due to the fact that in recent decades there has been a constant intensification of the processes of STP, globalization, a change in the paradigm of human resource management, the increasing role and importance of information, there is a need to form a permanent adaptation. At the same time,

\footnotetext{
Corresponding author:

${ }^{1}$ National University "Yuri Kondratyuk Poltava Polytechnic", Ukraine. E-mail: irinachernysh@gmail.com

ORCID: https://orcid.org/0000-0001-6565-5292

ResearcherID: https://publons.com/researcher/1937618/iryna-chernysh

${ }^{2}$ National University "Yuri Kondratyuk Poltava Polytechnic", Ukraine.

E-mail: mila.pesockaya@gmail.com

ORCID: https://orcid.org/0000-0002-7510-8839

ResearcherID: https://publons.com/researcher/4695364/mila-kozyk
}

adaptation is a protective reaction to changes, which allows you to assess them and determine the direction of further action. In professional activity to understand the reference points of cooperation with colleagues, acquaintance and acceptance (or rejection) of corporate values. The adaptation process is also important because it not only provides an introduction to the company and its standards of work, but also allows you to shape the behavior and culture of the future employee. It allows to assess strengths and weaknesses. 
Implementation of adaptation management system at the enterprise is quite a complex task, the solution of which affects: start-up costs, staff turnover, labor productivity, corporate culture. For new employees this aspect is especially important, as it affects their perception of new values, work rules and sense of belonging to a certain social group. For employees who work and move up the career ladder, anxiety, fear of the new team, tasks are reduced. For managers, adaptation allows not only to form a positive attitude to work, but also to save time in organizing their activities.

By paying attention to this from the beginning, hotel companies are able to reduce their investment in staff and increase productivity. That is, from the very beginning involve the employee in everything that is going on and thereby form a loyal attitude both to the company as a whole and to its activities by other employees, colleagues, friends, acquaintances. This process is especially important for the hospitality industry, where personnel play a crucial role.

The implementation of an adaptation management system in the hospitality industry is quite a complex task, the solution of which affects: start-up costs, staff turnover, productivity, corporate culture. For new employees this aspect is especially important because it affects their perception of new values, work rules and sense of belonging to a certain social group. For employees who work and move up the career ladder, anxiety and fear of the new team and tasks are reduced. For managers, adaptation allows them to form not only a positive attitude to work, but also saves time in organizing their activities.

For each category different adaptation tools are supposed to be used, the effectiveness of which will depend on a number of socio-economic factors. Therefore, first of all, it is proposed to consider the peculiarities of formation of managers' adaptation program on the basis of adaptation strategies (Table 1). These strategies, as a rule, are used by managers and specialists in the process of their professional growth.
The peculiarity of their adaptation is that they always feel pressure from above and below. Therefore, changes should not be abrupt, threatening to disrupt the work of other units. To do this, they use adaptation, which allows them not only to get acquainted with the new rules of work, but also to feel that their interests will be taken into account. At the same time, there are difficulties, which are associated with the difficulties of employees' perception of the new head. A new leader can only succeed if that leader is well-versed in the existing internal team relationships, relying on key figures, such as the temporary executor of those responsibilities. It is advisable to ask him for advice and discuss with him the possibilities of cooperation. This process will also be easier if the new leader studies the future of his subordinates, their strengths and weaknesses, qualifications, and potential opportunities for cooperation. It is also worth remembering that from day one it is desirable to show yourself as a person decisive, but at the same time cautious, prudent, who does not change everything at once, but immediately removes obstacles in the work. Pay attention to the opinions and suggestions of subordinates. Avoid criticizing the former supervisor. In this way, adapting the supervisor to the new work environment will reduce stress, tension, but also ensure high productivity.

\section{Adaptation of the personnel of enterprises in the field of hospitality}

For this purpose, as the world practice shows, specialized personnel adaptation services can be created. This can be done in different ways, depending on the number of employees at the enterprise, the management structure of the enterprise, the orientation of the administration of the enterprise to solve social problems in the sphere of production and other issues. The employee adaptation service is formed as an independent structural subdivision (department,

Table 1

Strategies for adapting leaders

\begin{tabular}{|l|l|}
\hline \multicolumn{1}{|c|}{ Strategy } & \multicolumn{1}{c|}{ Characteristics } \\
\hline 1. Expectations. & $\begin{array}{l}\text { It consists of a gradual study of the situation, careful attention to the evaluation of the predecessor's work, familiarity with } \\
\text { implemented and unimplemented projects, study of departmental problems and peculiarities of the previous manager's } \\
\text { work. The active action period usually begins after 100 days at the earliest. }\end{array}$ \\
\hline 2. Critical. & $\begin{array}{l}\text { Is the fact that the new manager is very critical and negative about the work of the previous manager, employees are } \\
\text { considered to be drones. Usually, active action begins 3-5 days in advance and assumes that the "new" supervisor will be } \\
\text { able to bring everything back to normal. }\end{array}$ \\
\hline 3. Traditional. & $\begin{array}{l}\text { Assumes that the new manager perceives the values and continues the work started. The new manager does not seek to } \\
\text { radically change anything, but rather follows the techniques of the previous manager. }\end{array}$ \\
\hline 4. Rational. & $\begin{array}{l}\text { It is based on the fact that the new manager chooses a few areas of activity to improve them and solve the pressing } \\
\text { problems within 4-6 weeks, which will get fast results. This allows the newcomer to succeed, to demonstrate his } \\
\text { capabilities. In the process of performing tasks, gradually train subordinates to work according to new rules, in } \\
\text { accordance with the set goals and not to "give up" even in the most difficult moment. }\end{array}$ \\
\hline
\end{tabular}

Source: (ISO 10018: 2015 Quality management; Kozak, Myronenko, 2019; Krushelnytska, Melnychuk, 2005) 
laboratory) or is part of other functional subdivisions (as a bureau, group and individual employees) - in the personnel department, sociological laboratory, labor and payroll department, etc. (Krushelnytska, Melnychuk, 2005). Sometimes the position of an adaptation specialist is added to the staff schedule. It is important that the adaptation service be an integral part of the overall HR management system at the enterprise. Consolidation of adaptation management functions can occur in the following areas:

1. Allocation of a separate structural unit, which will deal with the training and adaptation of employees. The adaptation unit should perform the following functions: study and forecasting of the situation on the labor market, implementation of appropriate restructuring of human resources; hiring and selection of personnel using professional profiles and job descriptions, testing and interviewing employees for the purpose of better adaptation; placement of personnel by departments, areas, jobs, formation of a stable workforce; organization of interaction with the regional adaptation management system on mutually beneficial terms.

2. Creation of separate positions, where the main task of specialists will deal with issues of adaptation, coordination of the work of production structural units in the process of reorganization, reduction, etc. Specialist responsibilities will include: 1) Introduction to the organization; characteristics; terms and conditions of employment; remuneration. 2) Submission to supervisor, immediate supervisor, training instructor. 3) Organization of an excursion to the workplace. 4) Explanation of working conditions, familiarization with the functions (together with the head). 5) Organization of training (together with the training department). 6) Introduction to the team, introduction of employees (together with the manager).

3. The development of mentoring, which allows the process of new employees adapting to the company to be shorter and more painless (Krushelnytska, Melnychuk, 2005). However, in today's realities, when changes occur dynamically, a number of tools are used for adaptation, which add up to a whole technology to solve not only the issue of adaptation, but also professional development (Table 2), which are used in domestic enterprises.

So, for example, in industrial enterprises the tool of adaptation of personnel is mentoring, in the service sector the technology of group coaching is used, namely such tools as, adaptation letter, training "Welcome!", corporate brochure and newcomer's kit. They are used to attract highly qualified specialists, develop the company and improve performance. Not large companies prefer internships and mentoring systems.

Analysis of world experience and scientific works of specialists allowed to form a list of modern tools for the adaptation of hospitality workers (Table 3).

Organizational decisions regarding the technology of the adaptation management process also include:

- organization of seminars, courses, etc. on various issues of adaptation;

Table 2

The essence and characteristics of personnel adaptation tools used in domestic enterprises

\begin{tabular}{|c|c|c|}
\hline $\begin{array}{l}\text { Staff adaptation } \\
\text { tools }\end{array}$ & Essence & Features \\
\hline Mentoring & $\begin{array}{l}\text { Provides on-the-job training by transferring skills, } \\
\text { knowledge, and abilities from an experienced professional } \\
\text { (colleague) for the purpose of the mentee's personal and } \\
\text { professional development. }\end{array}$ & $\begin{array}{l}\text { It lies in the fact that the mentoring process involves a } \\
\text { close connection (communication) between mentor and } \\
\text { subordinate. }\end{array}$ \\
\hline Coaching & $\begin{array}{l}\text { Provides adaptation through the analysis and } \\
\text { immobilization of internal capabilities through the } \\
\text { cooperation of the coach and the client. Development of an } \\
\text { individual system of continuous professional improvement, } \\
\text { transformation of weaknesses into strengths. }\end{array}$ & $\begin{array}{l}\text { A coach is not a leader or advisor, but rather a partner in } \\
\text { the professional development process who only nudges } \\
\text { rather than makes decisions. }\end{array}$ \\
\hline Adaptation letter & $\begin{array}{l}\text { An official document drawn up on an employee's first } \\
\text { day of work, along with the job description, by the line } \\
\text { manager. }\end{array}$ & To be made in writing or electronically. Optional. \\
\hline Days of beginners & Team building methods. & $\begin{array}{l}\text { This event is organized once a month or a quarter. This } \\
\text { event consists of two parts: formal and informal. }\end{array}$ \\
\hline Internship & $\begin{array}{l}\text { Provides a developed onboarding program and an } \\
\text { understanding of the employee's core business processes. }\end{array}$ & $\begin{array}{l}\text { Internships may be of varying lengths and involve } \\
\text { internships in various departments. }\end{array}$ \\
\hline Team training & $\begin{array}{l}\text { Provides an introduction to the company and colleagues in } \\
\text { the form of a game. }\end{array}$ & $\begin{array}{l}\text { It allows you not only to get to know your colleagues, but } \\
\text { also to form a relationship of trust and partnership. }\end{array}$ \\
\hline $\begin{array}{l}\text { New employee } \\
\text { folder }\end{array}$ & $\begin{array}{l}\text { Provides for the creation of a set of documents just for a } \\
\text { newcomer to the department activities, major business } \\
\text { processes, software packages (to solve individual tasks). }\end{array}$ & $\begin{array}{l}\text { It is made both in paper form and, possibly, in electronic } \\
\text { form. It is created at the initiative of the head of the } \\
\text { structural unit. It has a recommendatory character. }\end{array}$ \\
\hline
\end{tabular}

Source: summarized by the authors on the basis of (Bikova, Paranko, 2016; Didenko, Kozub, 2017; Krushelnytska, Melnychuk, 2005; Karabadzhak, 2013) 
Vol. 7 No. 5, 2021

Table 3

The essence and characteristics of adaptation tools used in foreign practice

\begin{tabular}{|l|l|l|}
\hline $\begin{array}{c}\text { Staff adaptation } \\
\text { tools }\end{array}$ & \multicolumn{1}{|c|}{ Essence } & \multicolumn{1}{|c|}{ Features } \\
\hline Secondment & $\begin{array}{l}\text { This method assumes that the employee is temporarily } \\
\text { transferred to a second department, a department, which } \\
\text { allows him to gain new knowledge and skills. After a } \\
\text { month, the employee returns to the workplace and to his/ } \\
\text { her previous duties. }\end{array}$ & $\begin{array}{l}\text { This method is used in flat organizations when } \\
\text { professional career development is limited. It allows you } \\
\text { to form a team in the company, improve communication } \\
\text { between employees and departments. }\end{array}$ \\
\hline Buddying & $\begin{array}{l}\text { Adaptation through a friendly, good relationship with a } \\
\text { colleague. This involves providing each other with honest, } \\
\text { objective information. Forming the necessary skills first of } \\
\text { all, and then performing the current tasks. }\end{array}$ & $\begin{array}{l}\text { Lack of hierarchy, "teacher-student" relations. Suggests } \\
\text { that relationships are built solely on propriety, advice, and } \\
\text { criticism. }\end{array}$ \\
\hline Shadowing & $\begin{array}{l}\text { Provides for the attachment of an experienced professional } \\
\text { who follows the student as a "shadow" and supervises him } \\
\text { or her as he or she performs professional duties. }\end{array}$ & $\begin{array}{l}\text { The result of such training is the formation of a clear and } \\
\text { unambiguous understanding of the philosophy, goals and } \\
\text { objectives of the activity. }\end{array}$ \\
\hline Learning by doing & $\begin{array}{l}\text { It involves learning by doing, where adaptation takes place } \\
\text { through learning and solving specific tasks. }\end{array}$ & $\begin{array}{l}\text { The main purpose of this method is to bridge the gap } \\
\text { between "what they say" and "what they do". }\end{array}$ \\
\hline Storytelling & $\begin{array}{l}\text { Provides training to employees through various stories, life } \\
\text { situations, and myths. }\end{array}$ & $\begin{array}{l}\text { This method is used when a newcomer comes to the } \\
\text { company for the first time. It allows the newcomer to get } \\
\text { acquainted with the philosophy, values, and culture of the } \\
\text { company. }\end{array}$ \\
\hline
\end{tabular}

Source: summarized by the authors on the basis of (Didenko, Kozub, 2017; ISO 10018: 2015 Quality management; Kozak, Myronenko, 2019; Krushelnytska, Melnychuk, 2005)

- conducting individual conversations of the head, mentor with a new employee;

- intensive short-term courses for aspiring executives;

- carrying out organizational and preparatory work in the process of innovative activity;

- special mentoring courses;

- using the method of gradually increasing the complexity of the tasks performed by a new employee.

At the same time, it is necessary to take care of control with a constructive analysis of the mistakes that are made in the performance of tasks.

It is advisable to think through a system of additional incentives for the employee for the successful solution of tasks;

- running one-time public assignments to establish a new employee's contact with the team;

- execution of one-time assignments to organize the work of the governing body (production meetings, the board of directors, etc.);

- training of personnel to replace employees during their rotation;

- conducting special role-playing games in the subdivision team to bring employees together and develop group dynamics (Krushelnytska, Melnychuk, 2005).

The employee receives many advantages (Table 3 ), the main of which are obtaining information necessary for effective work, relieving nervous tension arising in connection with the new job and entry into a new team, development of priority norms of the socio-cultural sphere of the enterprise.

For the hotel company there are also many benefits of effective adaptation, among them providing the organization with highly qualified personnel, reducing certain groups of costs, as well as increasing labor discipline and, of course, increasing profits. However, it should be noted that the most important factor of adaptation is motivational. The strength, stability, structure, and hierarchy of motives will determine the success and efficiency of adaptation and, accordingly, the further long-term continuous work of the subordinate. It is important that all adaptation tasks and actions in a hospitality enterprise be comprehensive and focused.

The signs of effective, successful adaptation are: conscientious performance of duties by new employees; responsible attitude to the tasks assigned, compliance with norms of behavior in the workplace, contacts with colleagues (joining formal and informal groups). The success of the candidate depends on a pre-designed program, which is not fully universal and must take into account the individuality of the person, allows you to achieve constructive results in a short time, which will increase the competitiveness of the enterprise and its economic security.

\section{Development of an adaptation based on ISO 10018: 2015 "Quality Management, Guidelines for Employee Engagement and Competencies"}

To improve the effectiveness of adaptation measures at the enterprises of hospitality, where one of the problems of personnel management is a high level of staff turnover and low level of development of 
Table 4

The advantages of adaptation for employees and the company depending on its type

\begin{tabular}{|c|c|}
\hline \multicolumn{2}{|c|}{ The advantages of effective adaptation. } \\
\hline For the employee & For the company \\
\hline \multicolumn{2}{|c|}{ Psychophysiological } \\
\hline Reducing fatigue levels & Reducing the cost of providing health care for employees \\
\hline \multicolumn{2}{|r|}{ Professional } \\
\hline $\begin{array}{l}\text { Formation of employees' professional competencies necessary for } \\
\text { effective functioning. } \\
\text { The most complete adaptation to the work process. }\end{array}$ & $\begin{array}{l}\text { Providing the company with highly qualified personnel. } \\
\text { Reducing staff turnover. } \\
\text { Reducing the number of errors caused by insufficient knowledge of } \\
\text { functional responsibilities. }\end{array}$ \\
\hline \multicolumn{2}{|c|}{ Socio-psychological } \\
\hline $\begin{array}{l}\text { The employee forms an idea of the structure of relations in the work } \\
\text { collective. } \\
\text { The employee acquires a social circle. }\end{array}$ & $\begin{array}{l}\text { Favorable socio-psychological climate that ensures the effective } \\
\text { operation of the enterprise. } \\
\text { No conflicts in the team. } \\
\text { Observance of production and technical discipline. } \\
\text { Increase of interest in work (increase in labor productivity). }\end{array}$ \\
\hline \multicolumn{2}{|c|}{ Organizational } \\
\hline $\begin{array}{l}\text { As a result of understanding what place an employee occupies in } \\
\text { the structure of the enterprise, an idea of his role in the overall } \\
\text { production process is formed. } \\
\text { As a result of acquainting the employee with the technology and } \\
\text { features of the activity, there is an understanding of what results } \\
\text { management expects from him or her. } \\
\text { Job satisfaction. }\end{array}$ & $\begin{array}{l}\text { The company receives an employee who has a clearly defined } \\
\text { position regarding his importance in the organizational structure of } \\
\text { the company. In this way it is ensured that the goals set for employees } \\
\text { are achieved quickly. } \\
\text { Reducing the costs associated with low efficiency. } \\
\text { Achievement of set goals in the shortest possible time. }\end{array}$ \\
\hline \multicolumn{2}{|c|}{ Primary } \\
\hline $\begin{array}{l}\text { Quick entry into professional activities. } \\
\text { Formation of professional competencies of employees. }\end{array}$ & $\begin{array}{l}\text { The ability to create a well-functioning team under the influence of } \\
\text { getting used to existing social relationships. } \\
\text { The company will get a confident employee, adapted to the team, } \\
\text { clearly aware of the need for his work for the company. }\end{array}$ \\
\hline \multicolumn{2}{|r|}{ Secondary } \\
\hline $\begin{array}{l}\text { Facilitate joining the team due to a job change or transition from one } \\
\text { department to another. }\end{array}$ & $\begin{array}{l}\text { Reducing costs associated with high staff turnover. } \\
\text { Improvement of team cohesion. }\end{array}$ \\
\hline
\end{tabular}

Source: (Krushelnytska, Melnychuk, 2005)

adaptation programs, it is proposed to use organizational support, namely a program based on ISO 10018: 2015 "Quality management, guidelines for employee engagement and competencies" (ISO 10018: 2015 Quality management, guidelines for employee engagement and competencies, ISO 10018: 2012).

The traditional adaptation program has traditional sections: about the history of the company; standards and rules of corporate culture; insurance and benefits; compliance with safety rules; career development; working conditions; the first interview; probationary period and individual program (taking into account the activities of each structural unit). Given that opportunities for self-development are increasing in the digital economy, modern programs should be supplemented with a section on self-development. And this should be reflected in the employee ID card.

This will ensure the formation of a talent pool of employees and increase productivity.

For this purpose, it is important to create a separate program of human capital development, a part of which will be an adaptation program that will ensure the positive attitude of hospitality enterprises. Such a program will focus on the development of competencies (Figure 1).

The main principles of the proposed human capital development program in the hospitality industry are as follows (Figure 2).

This program also requires the development of a number of standards that must be considered during the adaptation phase, when developing an individual program, which must take into account the following elements (Figure 3).

In addition, the implementation of this standard creates a need for other standards (Figure 4).

When implementing this standard, it will be necessary to harmonize all these standards on the basis of such a concept as "involvement" (interest). Because in all of these standards the following elements must be interrelated (Figure 5).

The peculiarity of this approach is the use of all these processes on the basis of the quality control cycle. This concept is proposed to be used from the perspective of "interaction and contribution to the achievement of common goals". 


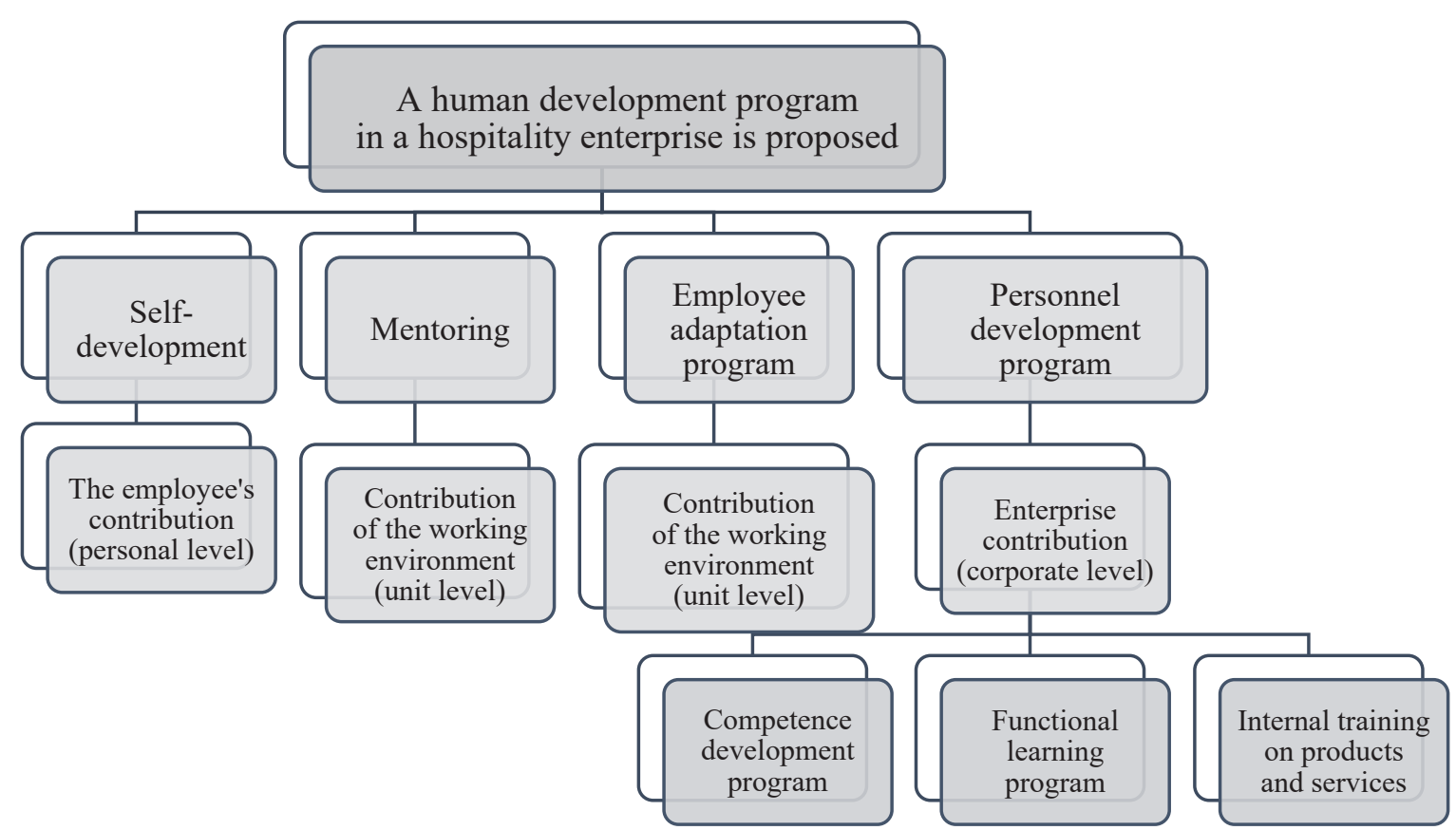

Figure 1. The program of human capital development of enterprises in the field of hospitality

Source: offered by author
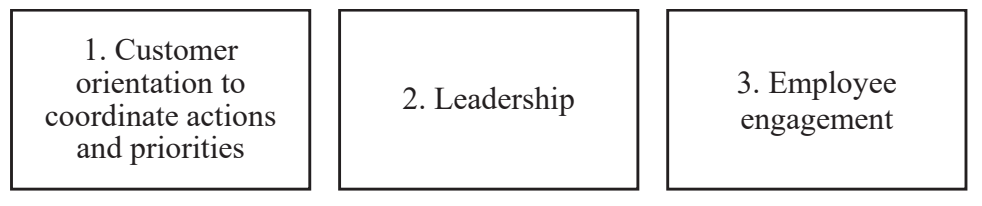

4. A process approach to provide system management

$$
\begin{aligned}
& \text { 5. A systematic } \\
& \text { approach } \\
& \text { to personnel } \\
& \text { management }
\end{aligned}
$$

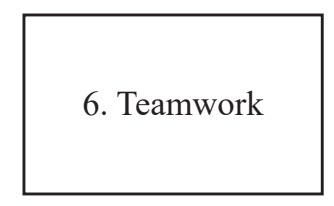
9. The factual approach to making management decisions
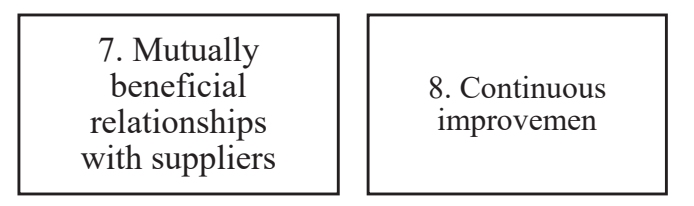

10. Quality management

Figure 2. The principles of human capital development program at the hospitality enterprises based on the standard ISO 10018: 2015 "Quality management, guidelines for employee engagement and competencies" are proposed

Source: by the author
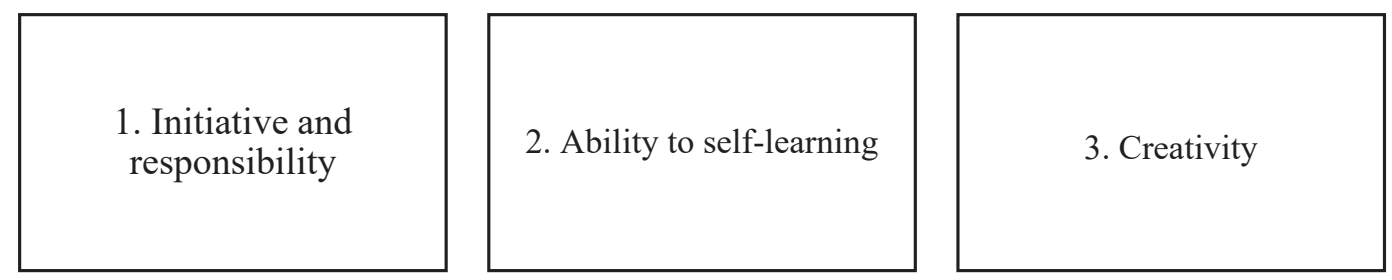

Figure 3. Qualities that should be included in the adaptation program of employees in the hospitality industry

Source: proposed by the author 


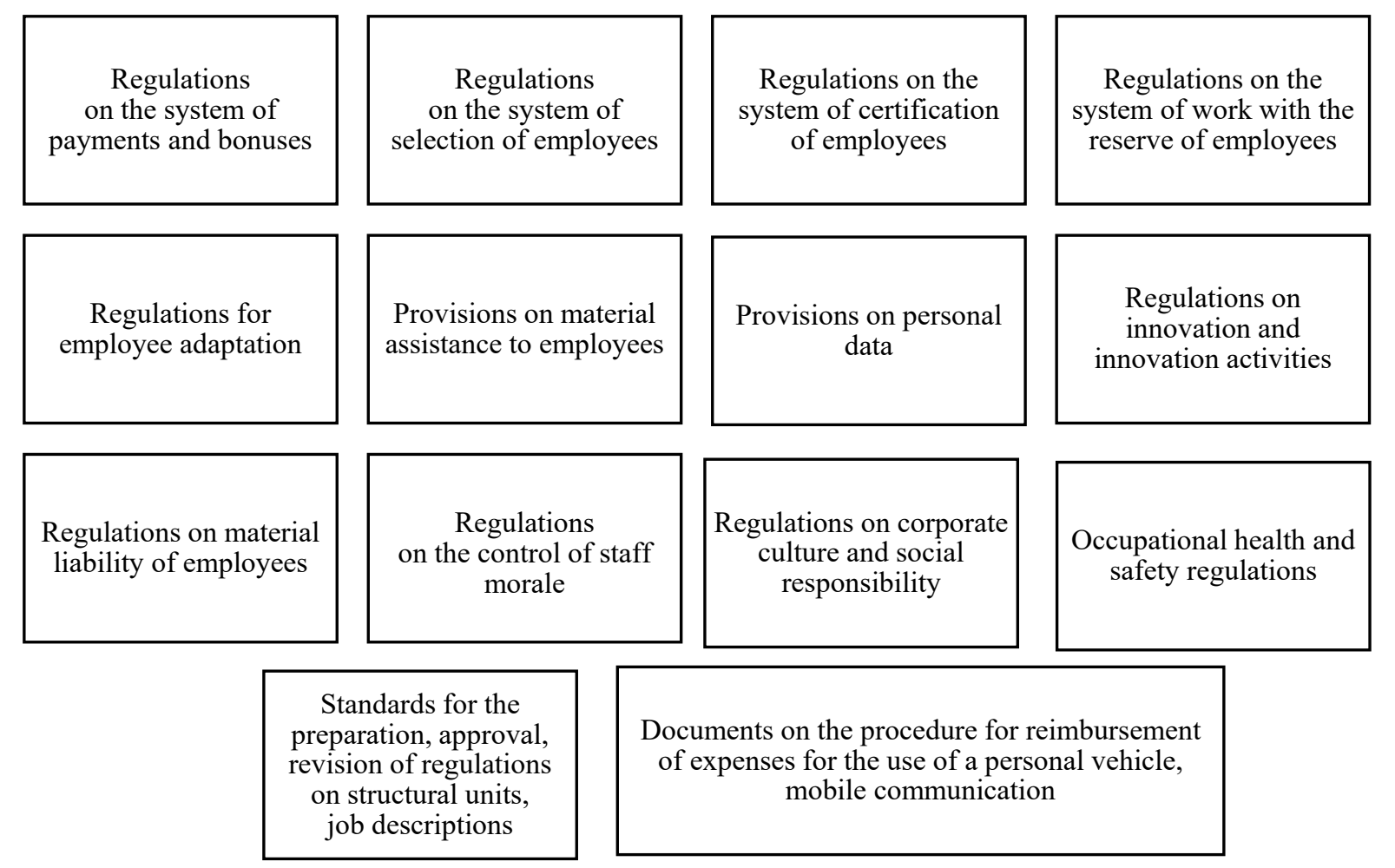

Figure 4. Basic standards that interrelate in the implementation of ISO 10018: 2015

"Quality management, guidelines for employee engagement and competencies"

Source: proposed by the author

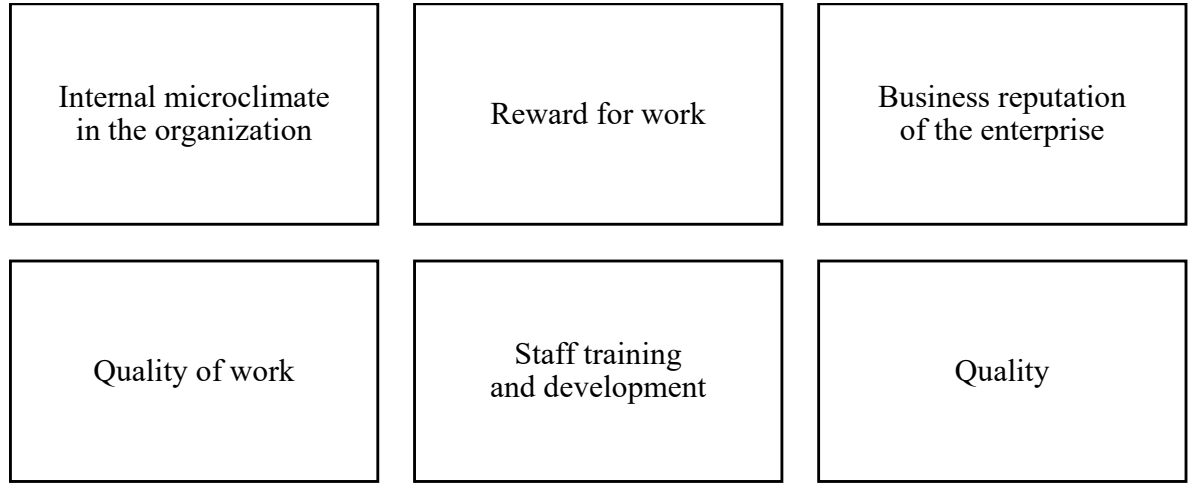

Figure 5. The main categories that relate to the concept of "engagement" in the standard ISO 10018: 2015 "Quality management, guidelines for employee engagement and competencies"

Source: proposed by the author

For this purpose, the standard contains recommendations for assessing employees' "engagement" and their "competencies". The advantage of this standard is that it provides for consideration from the very beginning of the competencies of the employee who will be hired until the moment of dismissal. That is, the process of "engagement" is carried out according to the PDCA cycle:

- analysis (collecting and analyzing information on short- and long-term goals for employee engagement and competencies);
- planning (procedures are developed and maintained to engage employees and their competencies at various levels (individual, group, organizational));

- implementation (introduction of plans and measures that should ensure the achievement of common goals based on the involvement and competence of employees);

- analysis (carrying out analysis and evaluation of plans, actions and obtained results for continuous improvement and involvement of employees). Thus, 


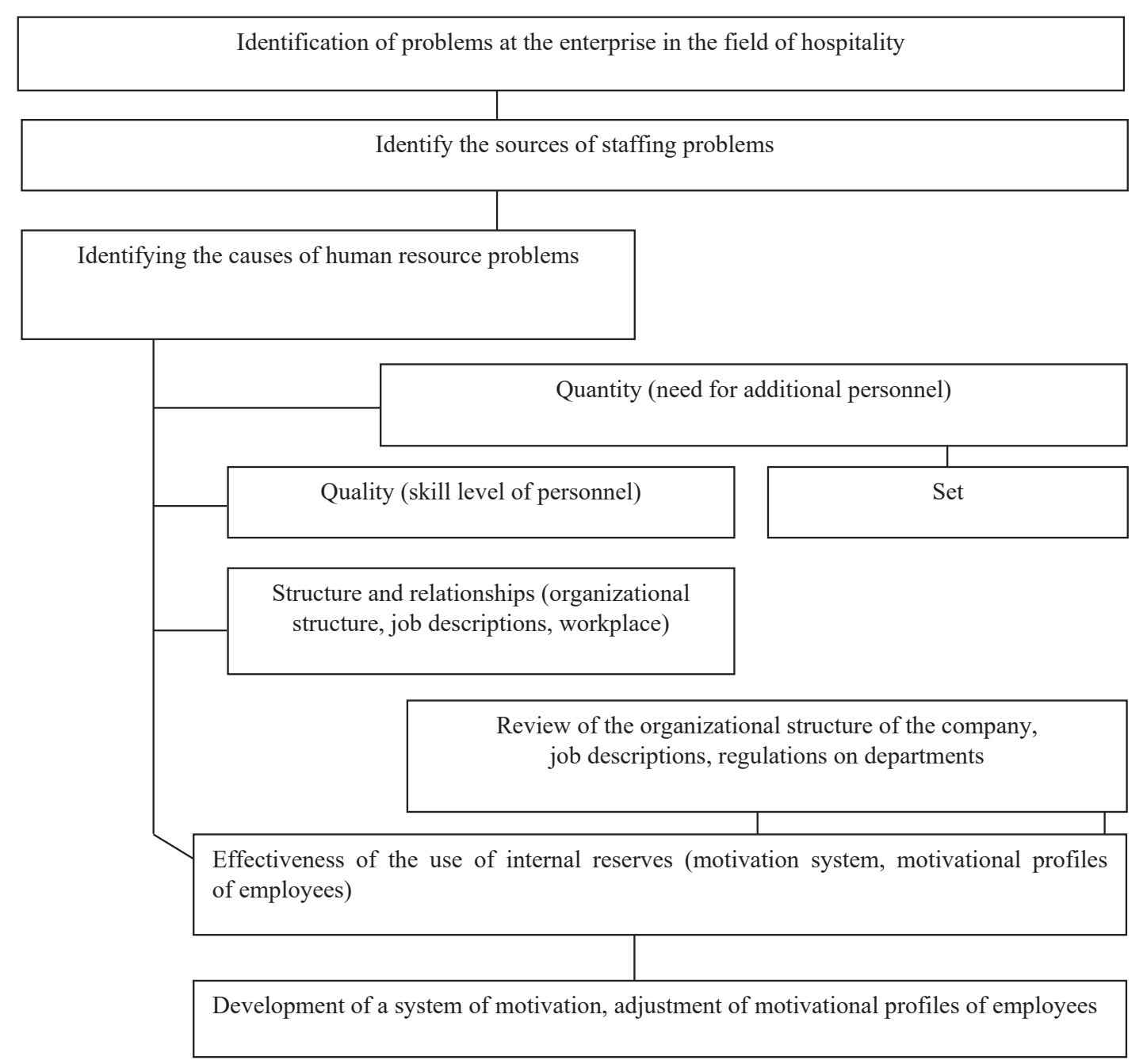

Figure 6. Algorithm for creating (adjusting) employee engagement and motivation in hospitality businesses based on ISO 10018: 2015 "Quality management, guidelines for employee engagement and competencies"

Source: proposed by the author

the standard contains an algorithm of interrelated processes that need to be agreed (Figure 6).

Thus, the implementation of this standard is harmonization of all documents, standards that relate to the process of personnel management in

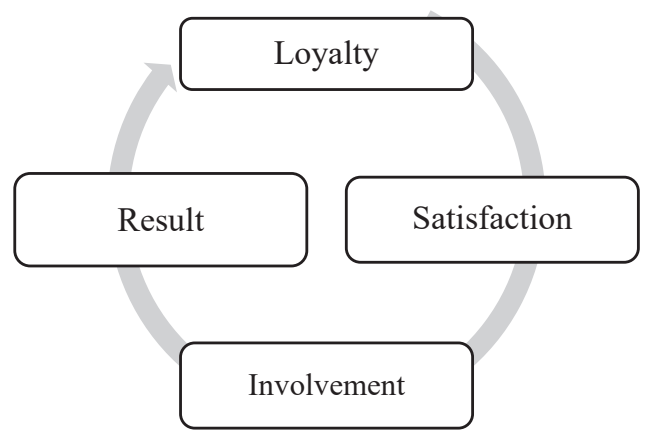

Figure 7. The main proposed categories to be introduced in the documentation of personnel management in the hospitality sector enterprises the hospitality industry. As a result of the implementation of this standard, the main categories that are important for management are implemented in the enterprises of the hospitality sector (Figure 7).

As a result of the implementation of this standard in the hospitality industry, the adaptation program should provide for the allocation of competencies for different categories of employees (managers, specialists, service personnel, etc.) (Table 4).

This will allow the adaptation process to be built in such a way that from the very beginning the employee is familiar with corporate values and is involved in organizational development.

\section{Conclusion}

Thus, there is a need to reflect the process of "engagement" in all the processes in which personnel are involved in the hospitality industry, from recruitment, to hiring, to graduation. Of course, in addition to the fact 
Table 4

Priorities that are determined in the process of selecting employees in hospitality enterprises based on the competency-based approach

\begin{tabular}{|l|l|}
\hline \multicolumn{1}{|c|}{ Staff category } & \multicolumn{1}{c|}{ Priorities } \\
\hline Staff & $\begin{array}{l}\text { customer orientation (friendly, cultural, attentive attitude); } \\
\text { willingness to work in accordance with the standards. }\end{array}$ \\
\hline Department specialists & $\begin{array}{l}\text { compliance with the corporate culture and values of the company; } \\
\text { correspondence to the professional qualities indicated by the applicant. }\end{array}$ \\
\hline Leaders & $\begin{array}{l}\text { skills in modern strategic management tools; } \\
\text { level of development of soft skills I hard skills. }\end{array}$ \\
\hline
\end{tabular}

Source: proposed by the author

that this will be reflected in the documents, there will be formed criteria by which candidates will be selected, it will be important to ensure an effective system of adaptation through mentoring and management support. Involving employees will motivate them to continuous development, and adaptation will not only ensure professional growth, but also the sustainable development of hospitality enterprises.

The use of ISO 10018: 2015 "Quality management, guidelines for employee engagement and competencies" will allow hospitality businesses to implement a planned and systematic process for the acquisition of employee competencies during their professional activities in the enterprise. To ensure the effectiveness of the management system, senior management should make effective choices about who to hire and under what conditions. To do so, they should also influence people's behavior to motivate them to work productively.
Whether as an individual or a group, the right kind of engagement can help generate ideas, build consensus and smooth the way for action plans. When combined with problem solving, decision making and processes, effective people engagement is a powerful tool for change and continuous improvement. Therefore, effective engagement of people requires a systematic approach, which is enshrined in ISO 10018: 2015 "Quality management, guidelines for employee engagement and competencies". Given that the competition among service enterprises is high, there is a need for further research on human capital by improving the organizational support of the personnel management process. Implementation of global adaptation experience, which will reduce time losses and increase the productivity of both administrative and service personnel.

\section{References:}

Bikova, A., \& Paranko, D. (2016). Components of effective staff adaptation. Young Scientist, (12): 640-646.

Brovchenko, N. (2012). Staff adaptation: to make the "stars" light up. Labor and law, (5): 32-33.

Didenko, Ye., \& Kozub, O. (2017). Science and practice: an innovative approach: Collection of scientific articles. Les Editions L'Originale, Paris, France: 241-246.

ISO 10018: 2015 Quality management. Guidelines on staff involvement and competence (ISO 10018: 2012, IDT). Corrected. Available at: http://online.budstandart.com/ua/catalog/doc-page?id_doc=66471

Kozak, K., \& Myronenko, B. (2019). The specifics of the use of outsourcing, outstaffing and leasing tools in the personnel management system. Economics of the food industry, (1): 73-79.

Krushelnytska, O., \& Melnychuk, D. (2005). Personnel management: a textbook. 2nd ed., Reworked: 38.

Karabadzhak, K. (2013). Methods of staff adaptation. Development management, (14): 19-21.

Moisieieva, N. (2015). Human adaptation to the communication space of modernity. Bulletin of the Book Chamber, (6): 38-40. 